Przegląd Badań Edukacyjnych Educational Studies Review

ISSN 1895-4308

nr 31 (2/2020), s. 209-218

KRÓTKIE ARTYKEY BADAWCZE

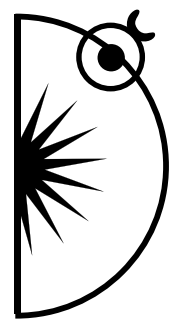

Edyta Widawska

ORCID: https://orcid.org/0000-0002-0964-0341

University of Silesia in Katowice, Poland, e-mail: edyta.widawska@us.edu.pl

Anna Pierzchała

ORCID: https://orcid.org/0000-0001-9529-5398

Jan Dlugosz University in Częstochowa, Poland, e-mail: a.pierzchala@ujd.edu.pl

\title{
Differentiation of Needs of Educators from Intercultural Perspective - with the Use of the Questionnaire of Educational Needs (QEN)*
}

http://dx.doi.org/10.12775/PBE.2020.027

\begin{abstract}
In this paper, the research presents findings that constitute an attempt to answer the research question relating to the way in which the educational needs of teachers are differentiated. Teachers belong to communities representing different cultural trends from the viewpoint of individualism. The research was conducted with the aid of QEN in the following four countries: Guatemala, Poland, Ukraine, and Great Britain $(\mathrm{N}=441)$. The resulting data was analysed by means of the Kruskal-Wallis $\mathrm{H}$ test for independent samples with reference to the following three needs: recognition, structure and stimulation. The research findings indicate that the cultural dimension the educators function in differentiates their educational needs. Nevertheless, the source of this would be worth searching for in other areas than the level of social individualism. The findings acquired may serve the planning of educational activities, while also guidelines to strengthen the intercultural dialogue.
\end{abstract}

Key words: teacher, need (hunger), educational transactional analysis, individualism.

* The research findings are part of the project relating to the application of transactional analysis which was executed within the framework of statutory grants from University of Silesia and Jan Dlugosz University. One of the effects of the project has been the preparation and verification of the following tool: the Questionnaire of Educational Needs. 


\section{Research questions}

By following the deliberations relating to the challenges for the educational system, it is possible to observe the trend relating to intercultural education, which is perceived not only as the process of passing on knowledge on the subject of other cultures, but first and foremost, as the creation of space for building a community of dialogue with the Other, accepting the differences and cooperating. This model requires perception and consideration in terms of pedagogical activities for the educational needs of their own, namely from the perspective of the teacher at hand, while also for the needs of people who actively participate in the process of learning. This provides the opportunity of creating an open and tolerant society, in which its members may operate effectively within their variations. The concept of intercultural identity (Nikitorowicz, 2011) is actually based on the combination of what is individual and what is of a universal dimension. This form of narrative on the subject matter of differentiation facilitates a broader view of the educational process. It is becoming a place to build individual cultural capital (Bourdieu \& Passeron, 1990), in which the role of the teacher does not merely come down to passing on knowledge. But also makes a teacher become a guide who animates the process of socialization for the effective functioning within diversity. One of the models of cultural differentiation is the concept of the cultural patterns by Geert Hofstede (2010), in which, among others, he emphasized the dimension of the social functioning of an individual and the associated relations with a group, which are registered in terms of the criteria of individualism versus collectivism. Societies in which the good of an individual is placed above the good of a group is defined in the category of individualistic societies. The reverse valuation qualifies a society in the collectivist category.

Groups of teachers were chosen for research from four countries representing various trends in this sphere- from Great Britain, with a result of 89 (on a 100 point scale), which places it among the countries with a high level of individualism, Poland (indicator of 60) Ukraine (indicator of 25) and Guatemala (indicator of 6), which belongs to the group representing a collectivist style of relations ${ }^{1}$. This way of describing social relations is interesting with regard to the problematic issues of education, in which one of the aims is socialization for the effective social functioning. The article attempts to answer the question of

${ }^{1}$ Data is derived from https://www.hofstede-insights.com/product/compare-countries/ (access provided: 19.08 .2020$)$. 
whether, and if so, how the educational needs of teachers who belong to societies representing various cultural patterns in terms of the level of individualism are differentiated. The needs are defined here in compliance with the concept of transactional analysis and have been divided into three groups specified in terms of hunger (Berne, 1966). The recognition hunger relates to the sphere of interpersonal relations and the state of being their subject. The structural hunger relates to the process of forming what is perceived to be a sequence of events that happen after each other, which have a specified framework. The stimulation hunger is associated with the mental and physical activity of the entity engaged in a didactic activity.

\section{Method}

The research was conducted with the aid of the Questionnaire of Educational Needs (QEN), which consists of 30 items (10 each for each form of hunger) and has four standardized language versions: Polish, British, Ukrainian and Spanish. The formula of responses is based on the 5-degree scale, which is codified in such a manner in order for the findings to indicate the intensity of the particular need.

The research was participated in by 441 educators from Poland $(\mathrm{n}=118)$, Great Britain $(n=104)$, Ukraine $(n=119)$ and Guatemala $(n=100)$. Women constituted $73.7 \%$ of the samples $(n=325)$, whereas men $21.5 \%(n=95)$, while gender was not declared by $4.8 \%$ people $(n=21)$. The average age amounted to 40.5 years of age, with a standard deviation of 9.27. With regard to the work experience, the respondents were possible to divide up into the following groups: work experience shorter than 5 years $-n=41 ; 5-10$ years $-n=102 ; 11-20$ years $\mathrm{n}=143$; over 20 years $-\mathrm{n}=137$. With relation to the research questions posed, the basic criteria for selecting the sample became the place of residence and the educational activity conducted. This is the source of imbalance in terms of the representation of people with regard to gender, age and work experience. The research was conducted in direct contact with the educators who had the possibility to complete the questionnaire.

\section{Findings}

With regard to the ordinal scale applied as a tool and the failure to comply with the condition of normality of the distribution of variables (W Shapiro-Wilk test), the findings analysis was carried out using the Kruskal-Wallis $\mathrm{H}$ test for independent samples (groups), thus acquiring the findings presented in Table 1. 
Table 1. Hungers differentiation - the Kruskal-Wallis $\mathrm{H}$ test for independent samples (groups)

\begin{tabular}{|c|c|c|c|c|c|c|}
\hline Need & Research location & $\begin{array}{l}\text { Average } \\
\text { ranking }\end{array}$ & $H$ & $x^{2}$ & $d$ & $p$ \\
\hline $\begin{array}{l}\text { Recognition } \\
\text { hunger }\end{array}$ & $\begin{array}{l}\text { UK } \\
\text { PL } \\
\text { UA } \\
\text { GT }\end{array}$ & $\begin{array}{l}226.15 \\
222.34 \\
290.64 \\
131.18 \\
\end{array}$ & 85.56 & 57.88 & 3 & 0.0000 \\
\hline $\begin{array}{l}\text { Structural } \\
\text { hunger }\end{array}$ & $\begin{array}{l}\text { UK } \\
\text { PL } \\
\text { UA } \\
\text { GT }\end{array}$ & $\begin{array}{l}183.49 \\
232.63 \\
267.94 \\
190.44\end{array}$ & 31.99 & 37.98 & 3 & 0.0000 \\
\hline $\begin{array}{l}\text { Stimulation } \\
\text { hunger }\end{array}$ & $\begin{array}{l}\text { UK } \\
\text { PL } \\
\text { UA } \\
\text { GT }\end{array}$ & $\begin{array}{l}215.29 \\
195.17 \\
239.01 \\
235.97\end{array}$ & 8.83 & 6.42 & 3 & 0.0316 \\
\hline
\end{tabular}

Source: Authors' research.

Simultaneously, the post-hoc tests applied indicate significant differentiation of the findings in the sphere of declarations relating to the forms of hunger felt among the representatives of the particular countries.

In the case of the recognition hunger, a particularly different group is constituted by the respondents from Guatemala, who indicated a lower need for recognition than the others surveyed. The highest need for psychological support is featured by teachers from Ukraine. The medians of responses amount to the following, respectively: $\mathrm{Me}_{\mathrm{GT}}=32, \mathrm{Me}_{\mathrm{PL}}=38, \mathrm{Me}_{\mathrm{GB}}=38$ and $\mathrm{Me}_{\mathrm{UA}}=42$. Respondents originating from Guatemala and Ukraine in accordance with the Hofstede concept, belong to collectivist societies. Hence, it is not possible to conclude that this cultural trend has a connection with intensification of the need for recognition among those analysed.

In the case of the structural hunger, teachers from Great Britain $\left(\mathrm{Me}_{\mathrm{GB}}=40\right)$ significantly differ from those analysed from Poland $\left(\mathrm{Me}_{\mathrm{PL}}=42\right)$ and Ukraine $\left(\mathrm{Me}_{\mathrm{UA}}=45\right)$, while the latter need greater organisation and clear understandable frameworks. The British are able to work efficiently in situations that are less unequivocal. Teachers from Ukraine also significantly differ from the educators from Guatemala $\left(\mathrm{Me}_{\mathrm{GT}}=38\right)$ by indicating the greater need for structure. Similarly, as in the case of the recognition hunger, the concept relating to the level of social individualism this may not constitute the basis for the explanation of the cultural differentiation of the respondents revealed here.

The least important differences found were in the case of the stimulation hunger. The differentiation at $\mathrm{p}<0.05$ is revealed in the case of teachers from 
Poland and Ukraine. Simultaneously, the respondents from Ukraine $\left(\mathrm{Me}_{\mathrm{UA}}=37\right)$ indicated a greater need in this sphere than their Polish counterparts $\left(\mathrm{Me}_{\mathrm{PL}}=34\right)$, which signifies their increased pursuit of mental and physical activation during the course of conducting didactic activities. Likewise, in this case a similarity with the findings is not found among teachers from more individualistic cultures.

The findings of the research conducted indicate that the cultural dimension, which the educators function in, is of significance for the preferred educational needs in accordance with the assumptions of the transactional analysis. At the same time, it is difficult to accept that the factor which explains the differentiation is that of the level of individualism of the society where the analysed people function. The sources of the differentiation found belong to other variables. The research findings acquired may serve the planning and execution of educational activities in differentiated groups from a cultural viewpoint as well as the formation of intercultural identity in homogenous groups.

\section{References}

Berne, E. (1966). Principles of Group Treatment. New York: Grove Press

Bourdieu, P. \& Passeron, J.C. (1990). Reproduction in Education, Society and Culture. London: Sage Publications.

Hofstede, G., Hofstede, G.J., \& Minkov, M. (2010). Cultures and Organizations: Software of the Mind. New York: McGraw Hill Professional.

Nikitorowicz, J. (2005). Kreowanie tożsamości dziecka [Creating a Child's Identity]. Gdańsk: GWP. 


\title{
Zróżnicowanie potrzeb edukatorów w perspektywie interkulturowej - wykorzystanie Kwestionariusza Potrzeb Edukacyjnych (KPE)*
}

\begin{abstract}
Abstrakt
W artykule przedstawiono wyniki badań stanowiących próbę odpowiedzi na pytanie badawcze w jaki sposób zróżnicowane są potrzeby edukacyjne nauczycieli należących do społeczności reprezentujących pod względem indywidualizmu odmienne wzorce kulturowe. Badania wykonano z zastosowaniem KPE w czterech krajach: Gwatemali, Polsce, Ukrainie, Wielkiej Brytanii $(\mathrm{N}=441)$. Dane analizowano za pomocą testu rang Kruskala-Wallisa dla prób niezależnych w odniesieniu do trzech potrzeb: rozpoznania, struktury, stymulacji. Wyniki badań wskazują, iż kulturowy wymiar, w którym funkcjonują edukatorzy różnicuje ich potrzeby edukacyjne. Natomiast źródeł tego warto poszukiwać w obszarach innych niż poziom indywidualizmu społecznego. Uzyskane wyniki mogą posłużyć do planowania działań edukacyjnych oraz wytycznych wzmacniających dialog międzykulturowy.
\end{abstract}

Słowa kluczowe: nauczyciel, potrzeby (głody), edukacyjna analiza transakcyjna, indywidualizm.

\section{Pytanie badawcze}

Śledząc dyskusje dotyczące wyzwań dla systemu edukacji dostrzec można nurt odnoszący się do edukacji międzykulturowej, rozumianej nie tylko jako proces przekazywania wiedzy na temat innych kultur, ale przede wszystkim stwarzania przestrzeni do budowania wspólnoty dialogu z Innym, akceptowania różnic i współpracy. Ten model wymaga dostrzegania i uwzględniania w działaniach pedagogicznych potrzeb edukacyjnych zarówno własnych, patrząc z perspektywy nauczyciela, jak i potrzeb osób, które w procesie nauczania czynnie uczestniczą. Daje to szansę na tworzenie społeczności otwartej, tolerancyjnej, której członkowie/członkinie sprawnie poruszają się w różnorodności. Koncepcja tożsamości międzykulturowej (Nikitorowicz, 2011) jest oparta właśnie na złączeniu tego co indywidualne z tym, co ma wymiar uniwersalny. Ten sposób narracji na temat różnorodności pozwala na szersze spojrzenie na proces edukacyjny. Staje się on bowiem miejscem budowania jednostkowego kapitału kulturowego (Bourdieu \& Passeron, 1990), w którym rola nauczyciela nie jest sprowadzona jedynie do

* Wyniki badań to część projektu, dotyczącego aplikacji analizy transakcyjnej i zostały zrealizowane w ramach grantów statutowych Uniwersytetu Śląskiego i Uniwersytetu Jana Długosza. Jednym z efektów projektu jest opracowanie i weryfikacja narzędzia: Kwestionariusz Potrzeb Edukacyjnych. 
przekazania wiedzy, ale czyni z niego przewodnika animującego proces socjalizacji do efektywnego funkcjonowania w różnorodności. Jednym z modeli zróżnicowania kulturowego jest koncepcja wzorów kultury Geerta Hofstede'a (2010), w której m.in. podkreśla się wymiar funkcjonowania społecznego jednostki i jej relacji z grupa, wpisanej w kryterium indywidualizm versus kolektywizm. Społeczności, w których dobro jednostki jest przedkładane nad dobro grupy, określa się w kategorii społeczeństw indywidualistycznych. Odwrotne wartościowanie kwalifikuje społeczeństwo do kategorii kolektywistycznych.

Do badań wybrano grupy nauczycieli z czterech krajów reprezentujących różne wzorce w tym zakresie - od Wielkiej Brytanii, z wynikiem 89 (na 100 punktowej skali), która plasuje się wśród krajów o wysokim poziomie indywidualizmu, przez Polskę (wskaźnik 60) i Ukrainę (wskaźnik 25) po Gwatemalę (wskaźnik 6), która należy do grupy reprezentującej kolektywistyczny styl relacji ${ }^{2}$. Ten sposób deskrypcji relacji społecznych jest interesujący w odniesieniu do problematyki edukacji, której jednym z celów jest socjalizacja do efektywnego społecznego funkcjonowania. Artykuł stanowi próbę odpowiedzi na pytanie czy, a jeśli tak, w jaki sposób zróżnicowane są potrzeby edukacyjne nauczycieli należących do społeczeństw reprezentujących różne pod względem poziomu indywidualizmu wzorce kulturowe. Potrzeby definiowano tutaj w zgodzie z koncepcją analizy transakcyjnej i podzielono na trzy grupy określane jako głody (Berne, 1966). Głód rozpoznania odnosi się do sfery relacji interpersonalnych i bycia ich podmiotem. Głód struktury dotyczy procesu kształcenia rozumianego jako ciąg następujących po sobie zdarzeń, które mają swoje określone ramy. Głód stymulacji jest związany z psychiczną oraz fizyczną aktywnością podmiotu zaangażowanego w działania dydaktyczne.

\section{Metoda}

Badania przeprowadzono z wykorzystaniem Kwestionariusza Potrzeb Edukacyjnych (KPE), który składa się z 30 itemów (po 10 na każdy z trzech głodów) i posiada cztery wystandaryzowane wersje językowe: polską, brytyjską, ukraińską i hiszpańską. Formułę odpowiedzi oparto o 5-stopniową skalę, zakodowaną następnie w taki sposób, by wyższe wyniki wskazywały na nasilenie danej potrzeby.

2 Dane pochodzą z: https://www.hofstede-insights.com/product/compare-countries/ (dostęp: 19.08.2020). 
W badaniu udział wzięło 441 edukatorów z Polski ( $\mathrm{n}=118$ ), Wielkiej Brytanii $(n=104)$, Ukrainy $(n=119)$ i Gwatemali $(n=100)$. Kobiety stanowiły $73,7 \%$ próby ( $\mathrm{n}=325)$, mężczyźni $21,5 \%(\mathrm{n}=95)$, płci nie określiło 4,8\% osób $(\mathrm{n}=21)$. Średnia wieku wyniosła 40,5 lat, odchylenie standardowe 9,27. Ze względu na staż pracy, respondentów podzielić można na następujące grupy: staż krótszy niż 5 lat $-\mathrm{n}=41 ; 5-10$ lat $-\mathrm{n}=102 ; 11-20$ lat $-\mathrm{n}=143$; powyżej 20 lat $-\mathrm{n}=137$. Ze względu na postawione pytanie badawcze, podstawowym kryterium doboru próby stało się miejsce zamieszkania i prowadzona aktywność edukatorska. Stąd nierównoliczna reprezentacja osób pod kątem płci, wieku i stażu zawodowego. Badania przeprowadzono w bezpośrednim kontakcie $\mathrm{z}$ edukatorami, którzy mieli możliwość wypełnienia kwestionariusza.

\section{Wyniki}

Ze względu na zastosowaną w narzędziu skalę porządkową oraz brak spełnienia warunku normalności rozkładu zmiennych (test W Shapiro-Wilka), analizę wyników przeprowadzono z wykorzystaniem testu $\mathrm{H}$ rang Kruskala-Wallisa dla prób (grup) niezależnych, uzyskując wyniki zaprezentowane w tabeli 1.

Tabela 1. Zróżnicowanie głodów - test H Kruskala-Wallisa dla prób (grup) niezależnych

\begin{tabular}{|c|c|c|c|c|c|c|}
\hline Potrzeba & Miejsce badania & Średnia ranga & $H$ & $x^{2}$ & $d$ & $p$ \\
\hline $\begin{array}{l}\text { Głód } \\
\text { rozpoznania }\end{array}$ & $\begin{array}{l}\text { UK } \\
\text { PL } \\
\text { UA } \\
\text { GT }\end{array}$ & $\begin{array}{l}226.15 \\
222.34 \\
290.64 \\
131.18\end{array}$ & 85.56 & 57.88 & 3 & 0.0000 \\
\hline Głód struktury & $\begin{array}{l}\text { UK } \\
\text { PL } \\
\text { UA } \\
\text { GT }\end{array}$ & $\begin{array}{l}183.49 \\
232.63 \\
267.94 \\
190.44\end{array}$ & 31.99 & 37.98 & 3 & 0.0000 \\
\hline Głód stymulacji & $\begin{array}{l}\text { UK } \\
\text { PL } \\
\text { UA } \\
\text { GT }\end{array}$ & $\begin{array}{l}215.29 \\
195.17 \\
239.01 \\
235.97\end{array}$ & 8.83 & 6.42 & 3 & 0.0316 \\
\hline
\end{tabular}

Źródło: badania własne.

Jednocześnie zastosowane testy post-hoc wskazują na istotne zróżnicowanie wyników w zakresie deklaracji dotyczących odczuwanych głodów pomiędzy reprezentantami poszczególnych krajów.

W przypadku głodu rozpoznania szczególnie odmienną grupę stanowią respondenci z Gwatemali, którzy wskazali na niższą potrzebę uznania niż po- 
zostali badani. Najwyższą potrzebą psychologicznego wsparcia cechują się nauczyciele z Ukrainy. Mediany odpowiedzi wynoszą odpowiednio: $\mathrm{Me}_{\mathrm{GT}}=32$, $\mathrm{Me}_{\mathrm{PL}}=38, \mathrm{Me}_{\mathrm{GB}}=38 \mathrm{i} \mathrm{Me}_{\mathrm{UA}}=42$. Respondenci pochodzący $\mathrm{z}$ Gwatemalii i Ukrainy, zgodnie z koncepcją Hofstede'a, należą do społeczeństw kolektywistycznych. Nie można zatem wnioskować, że ten wzorzec kulturowy ma związek z nasileniem potrzeby rozpoznania u badanych.

W przypadku głodu struktury nauczyciele $\mathrm{z}$ Wielkiej Brytanii $\left(\mathrm{Me}_{\mathrm{GB}}=40\right)$ istotnie różnią się od badanych $\mathrm{z}$ Polski $\left(\mathrm{Me}_{\mathrm{PL}}=42\right)$ i Ukrainy $\left(\mathrm{Me}_{\mathrm{UA}}=45\right)$, przy czym ci drudzy potrzebują większego uporządkowania oraz jasnych i zrozumiałych ram. Brytyjczycy są w stanie efektywnie pracować także w sytuacji mniej jednoznacznej. Nauczyciele z Ukrainy istotnie różnią się także od edukatorów z Gwatemali $\left(\mathrm{Me}_{\mathrm{GT}}=38\right)$, wskazując na wyższą potrzebę struktury. Podobnie, jak w przypadku głodu rozpoznania koncepcja dotycząca poziomu indywidualizmu społecznego nie może stanowić podstawy dla wyjaśnienia ujawnionego tutaj zróżnicowania kulturowego respondentów.

Najmniej istotnych różnic znaleziono w przypadku głodu stymulacji. Zróżnicowanie przy $\mathrm{p}<0.05$ ujawnia się $\mathrm{w}$ przypadku nauczycieli $\mathrm{z}$ Polski i Ukrainy. Przy czym respondenci pochodzący z Ukrainy $\left(\mathrm{Me}_{\mathrm{UA}}=37\right)$ wskazują na większą potrzebę $\mathrm{w}$ tym zakresie niż Polacy $\left(\mathrm{Me}_{\mathrm{PL}}=34\right)$, co oznacza ich zwiększoną dążność do psychicznego oraz fizycznego uaktywnienia w trakcie prowadzonych działań dydaktycznych. Również w tym przypadku nie ujawnia się podobieństwo wyników między nauczycielami z krajów o kulturze bardziej indywidualistycznej.

Wyniki przeprowadzonych badań wskazują, iż kulturowy wymiar, w którym funkcjonują edukatorzy, ma znaczenie dla preferowanych przez nich potrzeb edukacyjnych zgodnie z założeniami analizy transakcyjnej. Jednocześnie trudno przyjąć, iż czynnikiem wyjaśniającym to zróżnicowanie jest poziom indywidualizmu społeczności, w której funkcjonują badani. Źródeł ujawnionego zróżnicowania poszukiwać należy w innych zmiennych. Uzyskane wyniki mogą posłużyć do planowania oraz realizacji działań edukacyjnych w zróżnicowanych kulturowo grupach, a także dla kształtowania tożsamości międzykulturowej w grupach jednorodnych. 


\section{Bibliografia}

Berne, E. (1966). Principles of Group Treatment. New York: Grove Press

Bourdieu, P., \& Passeron, J.C. (1990). Reproduction in Education, Society and Culture. London: Sage Publications.

Hofstede, G., Hofstede, G.J., \& Minkov, M. (2010). Cultures and Organizations: Software of the Mind. New York: McGraw Hill Professional.

Nikitorowicz, J. (2005). Kreowanie tożsamości dziecka. Gdańsk: GWP. 